

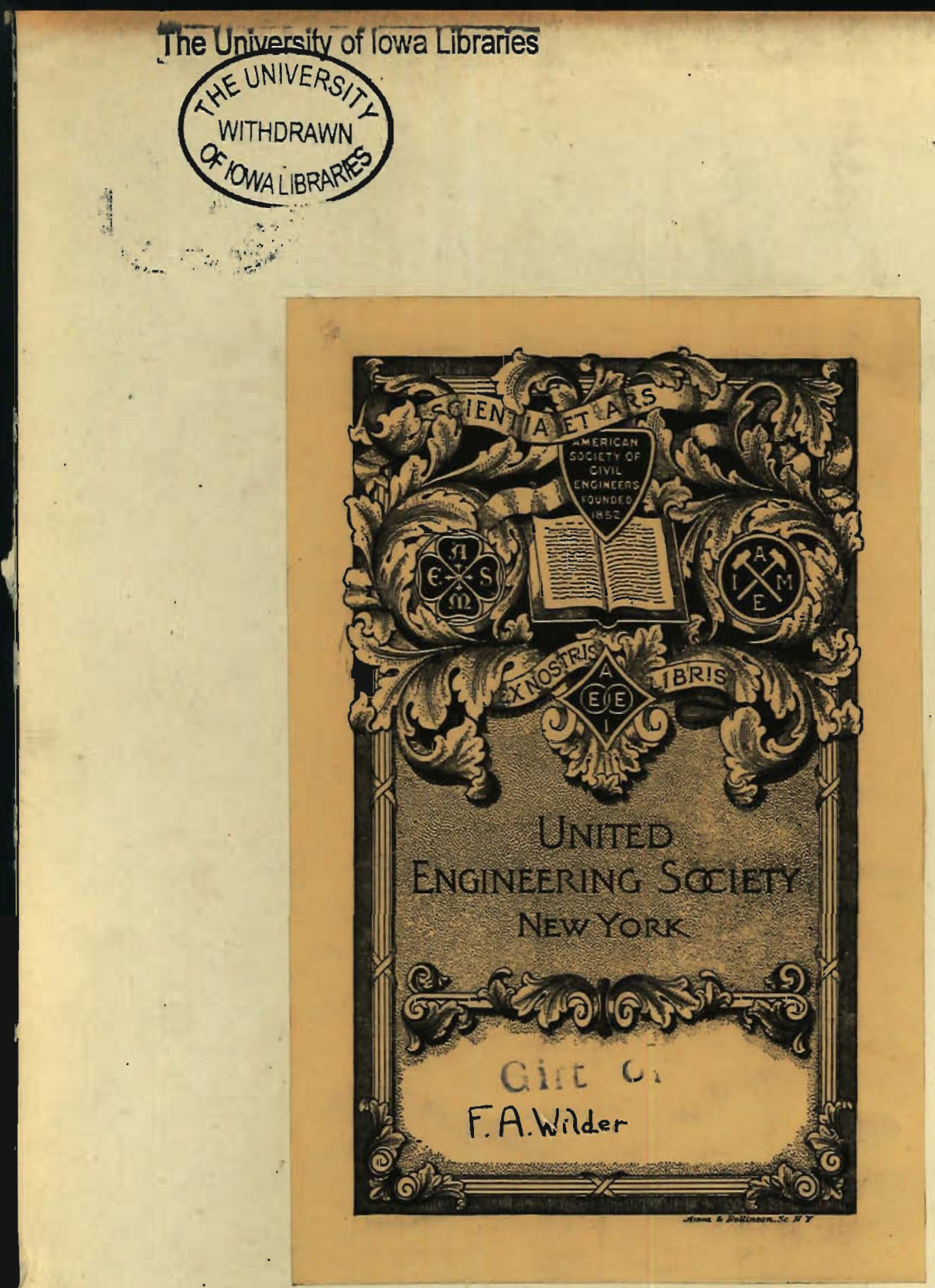




\section{IOWA \\ GEOLOGICAL SURVEY}

VOLUME XXVIII

$\underset{\text { Annual Reports, } 1917 \text { and } 1918}{\text { with }}$

Accompanying Papers

GEORGE F. KAY, Ph. D., State Geologist

JAMES H. LEES, Ph: D., Assistant State Geologist 


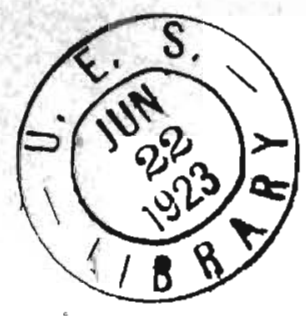

557.77

I 9 r 5 


\section{Geological Survey Organization}

\section{GEOLOGICAL BOARD}

His Exceilency, W. L. Harding.

GOVERNOR OF IOWA

Hon. Frank S. SHaw.

AUdiTor OF STATE

Dr. Walter A. Jessup. President State Unrerisity

Dr. Raymond A. Pearson President Iowa State College

Professor Luther S. Ross President Iowa ACADEMY OF Science

\section{ADMINISTRATIVE OFFICERS}

George F. Kar. STAte Geologist

JAMES H. LEES Asst. State Geologist NEILIE E. NEWMAN. SECRETARY

\section{GEOLOGICAL SECTION}

Georae F. Kay

Pleistocene Geology JAMES H. LEES WM. H. NORTON .Stratigrapuic aNd Areal Geology

S. W. BEYER UNDERGROUND WATERS

B. SHTMEK Economic Geology, Clays

F. A. WILDER ..AREAL GEOLOGY JOHN L. TUTON. Economic Geology, Gypsum . Swney L. GaIJiN STratigRaPHIC GEOLOGY F. M. VAN TOYL Economic Geology, Clays

Walter H. Scholwe. STRATIGRAPHIC GEOLOGY

J. E. CARMAN AREAT GEOLOGY

A. O. Thomas. Areal Geolocy

W. V. KNOLL STRATIGRaPHIC GEOLOGY JOHN E. SMYTH. Areat Geology ED. RODDEWIG Geology, Clays

A. E. JFNNINGS ..Chemist, Clays

J. N. Pearce. .Chemist, GyPSUM

DAYTON STONER Chemist, Pleistocene Clays Broloaist, RODENTS

\section{WATER GAGING SECTION}

R. H. Bolster

HYDROGRAPHIC ENGINEER

C. HerLOFsON District EngtneER 


\section{CONTENTS}

Ther OFGE

Mineral Production in Iowa in 1917 and 1918, James H. Lees

GXPsum: Its OCcurrence, Origin, Technology and Uses, Frank A. Whider 47

Preface ...

Chapter I, Physical and Chemical Properties of Gypsum..................................... 63

Chapter II, Important Deposits of Gypsum in the United States and

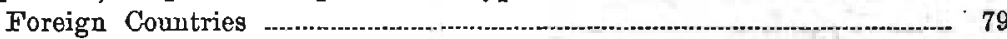

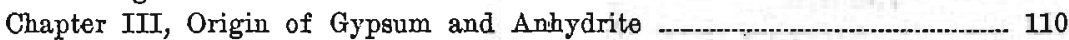

Chapter IV, General Descriptions of the Iowa Gypsum Fields ..................... 130

Chapter V, Stratigraphy of the Iowa Gypsum Areas .................................... 136

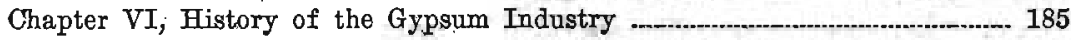

Chapter VII, Physical and Chemical Characteristies of Iowa Gypsum ....... 200

Chapter VIII, Technology of Gypsum and Gypsum Plaster ..............................

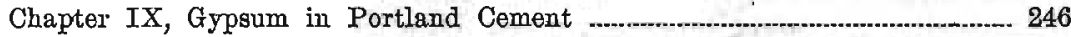

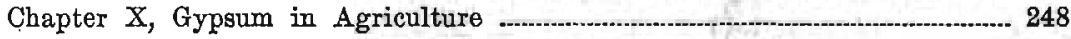

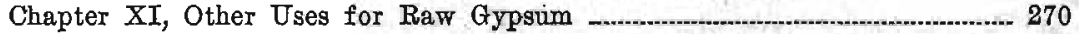

Chapter XII, Chemical, Characteristics of Calcined Gypsum ............... 273

Chapter XIII, Physical Properties of Calcined Gypsum ............ 279

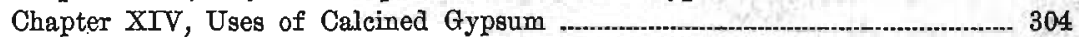

Chapter XV, Composition and Properties of Gypsum Plasters ..................... 308

Chapter XVI, Gypsum Blocks for Floors, Walls and Roofs .................... 322

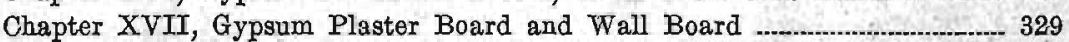

Chapter XVIII, Structural Gypsum …. 342

Chapter XIX, Hydraulic Gypsum and Keene's Cement …......................... 354

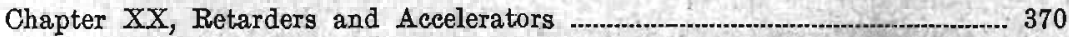

Chapter XXI, Hardening and Coloring of Gypsum and Calcined Gypsum 373

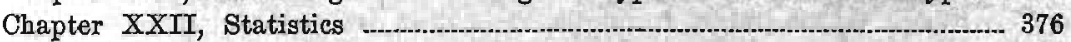

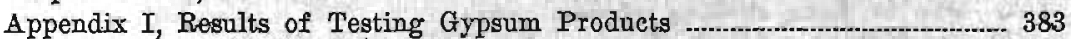

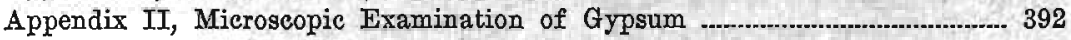

Appendix IIT, German Methods of Testing Gypsum …_. 400

Appendix IV, Measurement of Time of Set of Calcined Gypsum …....... 407

Appendix V, Factors Influencing. Time of Set of Calcined Gypsum …_- 419

Appendix VI, Gypsum Composition Slab Construction for Roofs and Floors 426

Appendix VII, Emley Patent for Plastic Gypsum …...................... 44

Appendix VIII, Design of Reinforced Gypsum Beams ......................... 454

Appendix IX, Gypsum Companies in United States, Mexico and Canada, 1921

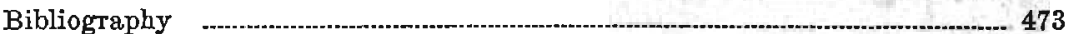

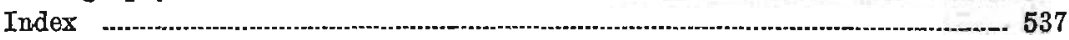

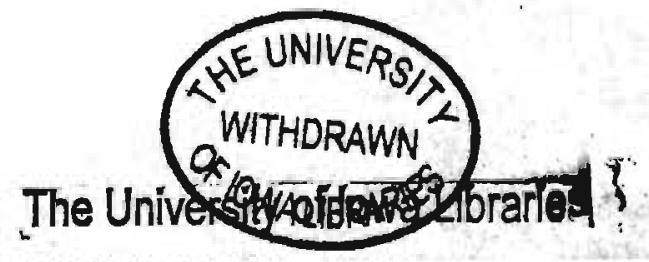




\section{LIST OF ILLUSTRATIONS}

I. Topographic and geologic map of Fort Dodge Region.

II. Selenite Crystals from Centerville

III. Map showing location of gypsum deposits and mills in the United States

IV. Map showing location of gypsum bearing deposits of Nova Scotia and

New Brunswick

V. Gypsum near Des Moines river

VI. Cross sections along Des Moines valley and Soldier and Lizard creeks 176

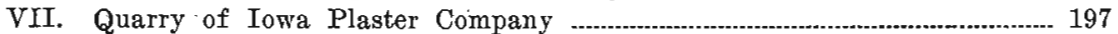

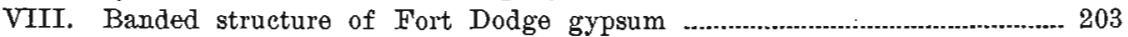

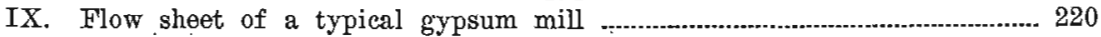

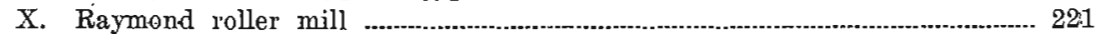

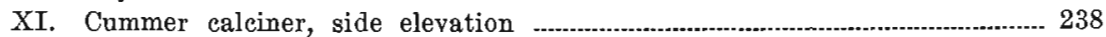

XII. Diagram showing fuel and power consumption in Gypsum industry,

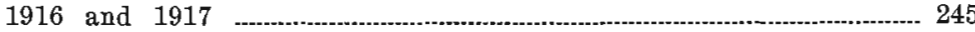

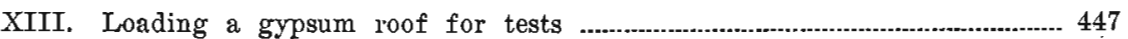

FIGURES PAGE

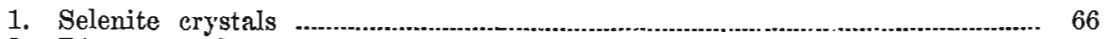

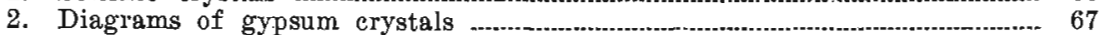

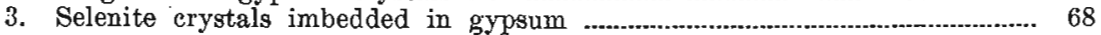

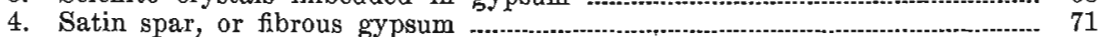

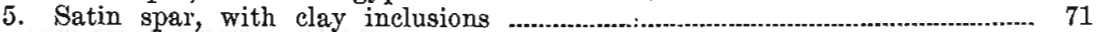

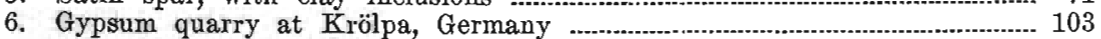

7. Sketch showing precipitation of salts from sea water -a- 113

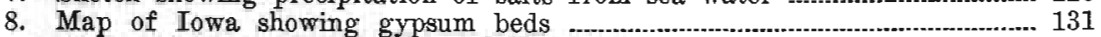

9. Airplane view of the Soldier creek valley, Fort Dodge ......................... 137

10. Shales and sandstones near lower viaduct over Soldier creek, Fort Dodge 139

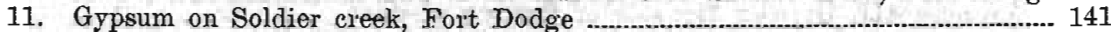

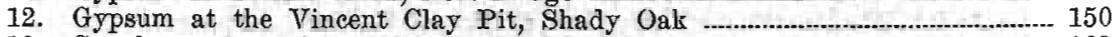

13. Conglomerate at base of Fort Dodge beds ................................................... 169

14. Keyes' section across the gypsum area

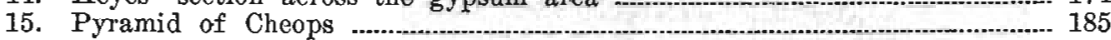

16. Egyptian calcining oven ….... 186

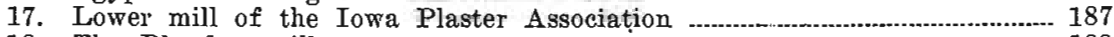

18. The Blandon mill 188

19. The Cardiff mill, the first mill on the prairie ................................................. 189

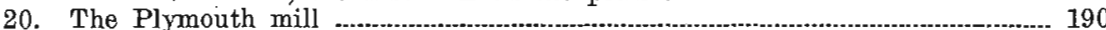

21. American Cement Plaster Company Mill ....................................................... 191

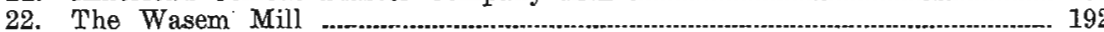

23. The Iowana Mill ....... 193

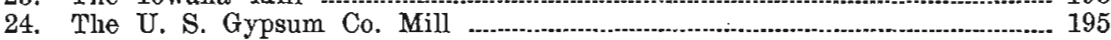

25. The Centerville Mill .............. 199

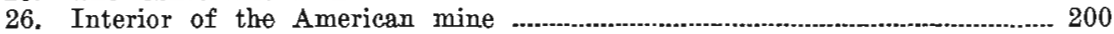

27. House in Fort Dodge built of gypsum .............. 201

28. Domes in Gypsum Hollow .......................................................................... 202

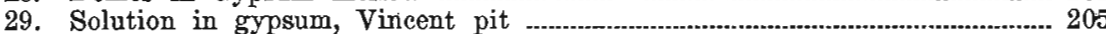

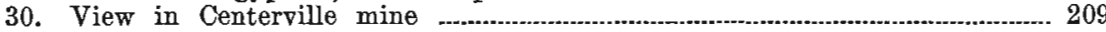


31. View in Plymouth mine ............................................................................. 212

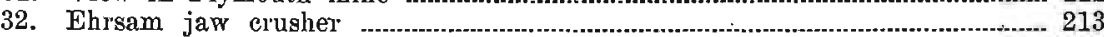

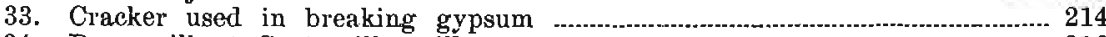

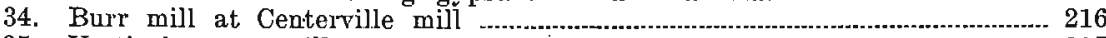

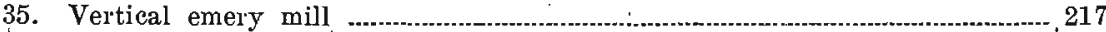

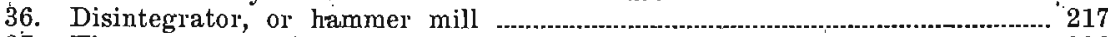

37. Fineness tests of 1922 .............. 226

38. Effect of grinding on setting time and rise in temperature ....................... 227

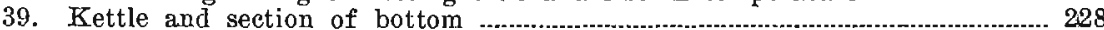

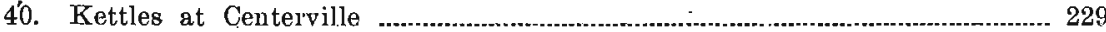

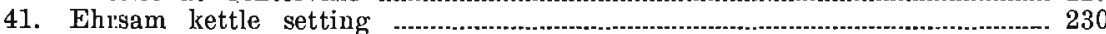

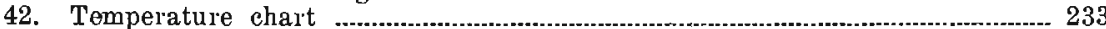

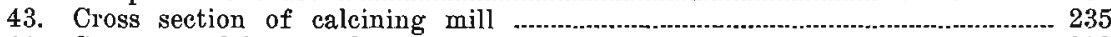

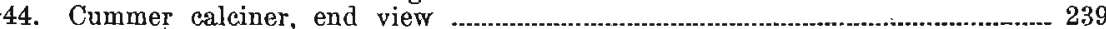

45. Ehrsam mixer -

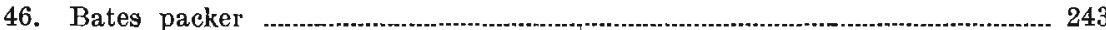

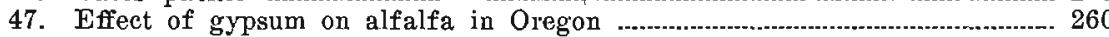

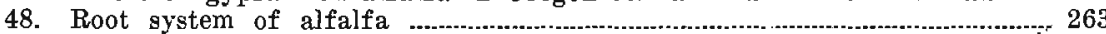

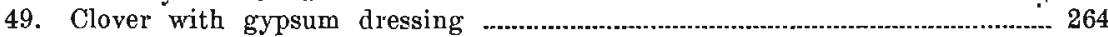

50. Pot culture showing effect of sulphates on plants ...................................... 266

51. Temperature curve during calcining ............................................................. 275

52. Vicat needle .

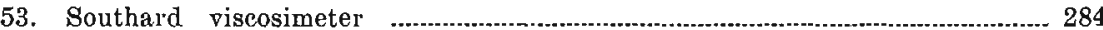

54. Curre of setting time ................................................................................. 288

55. Temperature progress in gypsum eating of pillar .................................. 292

56. Temperature progress in gravel concrete .................................................. 293

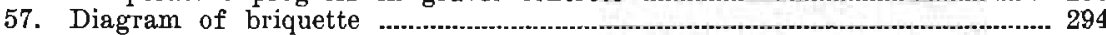

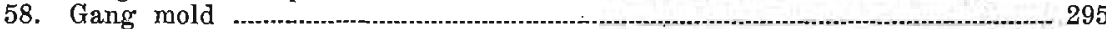

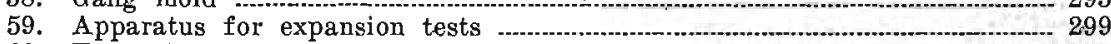

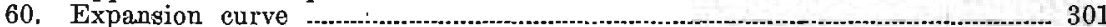

61. Tensile strength, mixture of gypsum and Portland cement ..................... 302

62. Diagram of block machine .......................................................................... 324

63. Gypsum blocks as fire proofing -.... 325

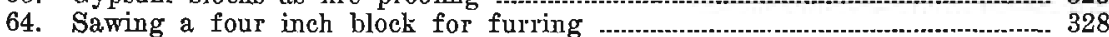

65. Penetration by gypsum in plaster board .................................................... 331

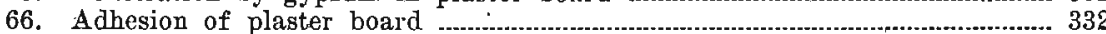

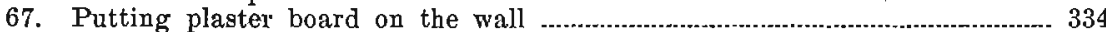

68. Plaster board and coatings

69. Plaster board ceilings, Maywood hospital .................................................... 338

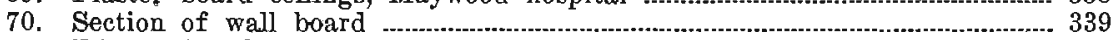

71. Effect of hydrated lime on compressive strength

72. Reinforcement in the Hammerstein theatre ................................................... 348

73. Making precast gypsum roof tile ............................................................... 351

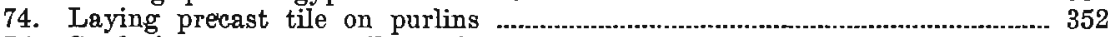

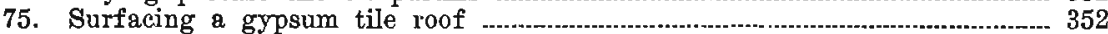

76. Gypsum floor deck .......................................................................................... 353

77. Diagram showing Estrich kiln -

78. Cross section of kiln for burning hydraulic gypsum ........................... 357

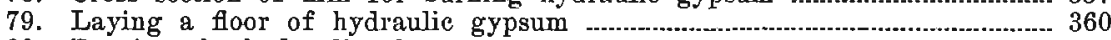

80. Pouring the hydraulic plaster

81. Distributing the mortar

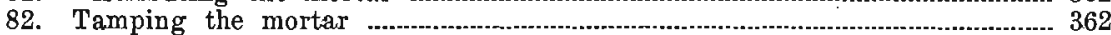

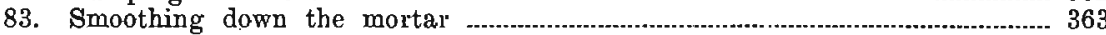

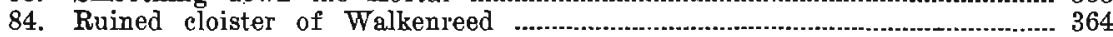

85. Modern building using gypsum plaster ............................................................ 365

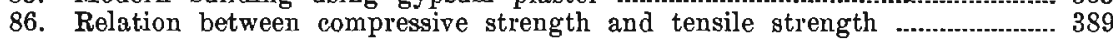

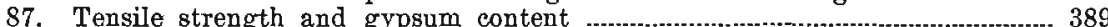

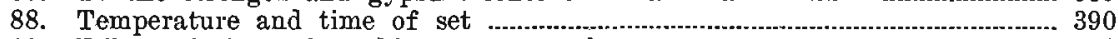

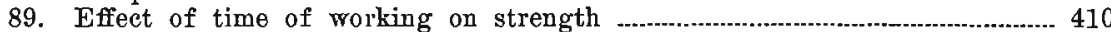

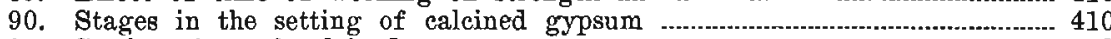

91. Setting time of calcined gypsum

92. Expansion of calcined gypsum while setting .................................................. 412 
93. Temperature changes in calcined gypsum while setting

94. Time intervals for initial and final set

95. Relation between water used and setting time

96. Relation of water used to viscosity

97. Effect of stirring on time of set

99. Effect of temperature of water used in mixing on time of set ................ 424

100: Sections showing loading test of gypsum composition floor

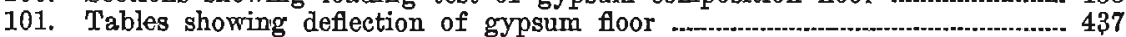

102. Plans showing measurements of gypsum composition floor ...................... 438

103. Curves showing deflection of supporting beams .

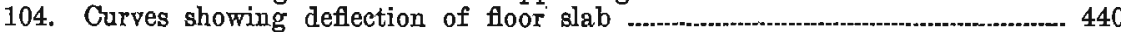

105. Curves showing elongation of reinforcing cables .......................................... 442

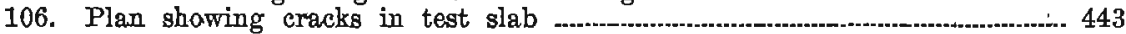

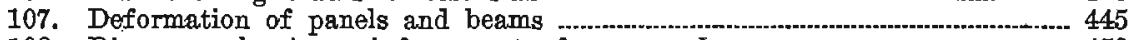

108. Diagrams showing reinforcement of gypsum beams ..................................... 459

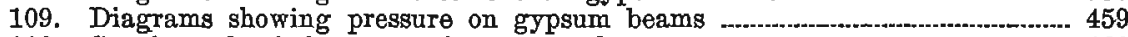

110. Spacing of reinforcement in gypsum beams

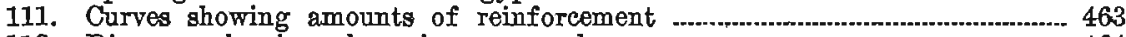

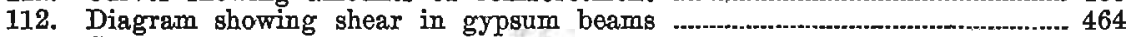

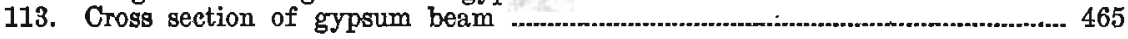

